\title{
Peach Rootstocks for the United States: Are Foreign Rootstocks the Answer?
}

Gregory L. Reighard

Additional index words. Prunuspersica, nematodes, soil diseases, soil texture, cold hardiness, tree size control

Summary. N ew foreign rootstocks for peaches [Prunus persica (L.) Batsch] are now being introduced into the U nited States through commercial nurseries for future sales to stone fruit growers. Almost all of these rootstocks are complex Prunus L. hybrids that are propagated vegetatively. Past experience with foreign Prunus rootstocks has shown that extensive testing is critical to avoid potential problems in commercial situations due to nonadaptation of some rootstocks to $\mathrm{N}$ orth American climatic and edaphic conditions. In addition, putative resistance of introduced rootstocks to common soil diseases and other pathogens has not always carried over to orchard sites in the U nited States. To ensure widespread horticultural testing of new rootstocks, the N C-140 regional research group continues to serve as an unbiased tester in many different geographic and production areas of the $U$ nited States and $C$ anada.

$\mathrm{E}$

conomic viability of a fruit production enterprise is linked directly to orchard productivity and management efficiency. To increase productivity and efficiency requires tree survival, managed vigor, and increased marketable yields over the expected life span of the orchard. The growers' choice of rootstock is often as important if not more so than the scion variety whenever peaches are grown on soils having high bulk density, parasitic nematodes, root rot fungal pathogens, or other edaphic or replant problems. If one or more of these conditions are present, peach tree survival and growth can be improved significantly by selecting the appropriate rootstock for each soil or site situation. A longtime limitation to peach production has been the absence of rootstocks that moderate vigor or are tolerant to undesirable soil properties, site characteristics, and soilborne pathogens. As good orchard sites become scarce and chemical control practices become cost-prohibitive or unavailable, new rootstocks need to be found to solve soil and site problems which were corrected previously by orchard relocation or chemical fumigation.

D epartment of H orticulture, Clemson U niversity, Clemson, SC 29634-0375.

The cost for publishing this paper was defrayed in part by the payment of page charges. U nder postal regulations, this paper therefore must be hereby marked advertisement solely to indicate this fact. 
$M$ any new rootstocks for peach have been released in the past 20 years in Europe(L oreti, 1994; L oreti, 1997) and now are becoming available for testing in the $U$ nited States (T able 1 ). Thispaper discusses so me of thesenew rootstock releases and their potential for solving some of the specific soil and site problems that U .S. peach growers currently are experiencing.

\section{Biotic and abiotic soil factors affecting peach rootstocks}

Parasitic nematodes. M any nemato de species successfully parasitize peach roots and frequently reduce peach tree growth and survival. Four types of nematodes are recognized as injurious to peach trees in North America (N yczepir and Becker, 1998). They are the ring [Criconemella xen oplax (Raski) L uc \& Raski], rootknot [M eloidogyne incognita (Kofoid \& White) Chitwood, M. javanica (T reub) Chitwood, M . arenaria ( $\mathrm{N}$ eal) Chitwood, and M. hapla Chitwood], lesion [Pratylenchus vulnus Allen \& Jensen and $P$. penetrans ( $C o b b)$ Chitwood \& Oteifa] and dagger (Xiphenema americanum Cobb) nematodes. R ootstocks often are categorized as immune, resistant, tolerant or susceptible to nematodes. For a specific nematode species, rootstocks labeled asimmune or resistant are poor or nonhosts for nematode survival and reproduction and are not impacted by nematodefeeding. Tolerant rootstocks are fair to good hosts for a specific nematode, but nematode reproduction and feeding does not significantly alter the rootstock's ability to supply the scion's mineral, hormonal and water requirements to survive, grow and bear fruit. Rootstocks susceptible to a specific nematode are good hosts for nematode reproduction and are impacted negatively by nematode feeding in areassuch astreesurvival, growth and fruiting.

Ring nematode has been linked directly to the onset of peach treeshort life (PTSL) syndrome in the Southeast (N yczepir et al., 1983; Zehr et al., 1976). M any new foreign rootstocks have not been tested for reaction to ring nematode. However, older (1980s) rootstock introductions (Grasselly, 1987; Renaud et al., 1988) such as the French peach seedling rootstocks M ontclar, Rubira, GF 305, and $\mathrm{H}$ igama, and the plum hybrids 'I shtara' and 'M yran', were good hosts for ring nematode (Westcott et al., 1994) and were susceptible to PTSL (G.L. Reighard, unpublished data). $\mathrm{No}$ foreign rootstock survived better in field tests in South Carolina and Georgiathan theregionally developed BY520-9 (now Guardian) (O kie et al., 1994; Reighard et al., 1997).

Root-knot nemato des cause serious growth reduction in peach trees grown in warmer regions. There are at least four species of root-knot nematode ( $M$ eloidogynearenaria, M . incognita, M. javanica, M. hapla) as well as a number of races within each species that feed on peach. $M$. incognita and $M$. javani ca are the most common on peach in the U nited States. M any peach rootstocks were introduced for rootknot nematoderesistancein theU nited States in the $20^{\text {th }}$ century (D ay, 1953). These included Shalil, Yunnan, O kinawa, and $\mathrm{H}$ igama. All of these rootstocks either were not resistant to $M$. javanica or had other problems and eventually were replaced by domestically developed rootstocks such as $\mathrm{N}$ emaguard, $\mathrm{N}$ emared, Flordaguard, and Guardian.

Recent introductions still not evaluated in the U nited Statesfor rootknot resistance includethel talian rootstocks 'Barrier 1' $[P$. persica $\times$ P. davidiana (Carr.) Franch.], 'Penta' and 'T etra' (P. domestica L.), theSpanish rootstocks 'Adesoto 101'( $P$. insititia L.) and 'Adarcias', ' $G \times N$ 8', ' $G \times N$ 15' and ' $G \times N$ 22' (all P. dulcis (M ill.) D.A. Webb $x$ P. persica), the French rootstocks ' $M$ yran', a cross of 'Belsiana' ( $P$. cerasifera Ehrh. x P. salicina Lindl.) and 'Yunnan' peach, and 'I shtara', a cross of 'B elsiana' and $a P$. persica $x P$. cerasifera hybrid. $M$ any of the above introductions have been evaulated for root-knot resistance in E urope and some of the resistant ones reported are 'Barrier 1', 'Tetra', 'A desoto 101', 'G x N 15', 'G x N 22' and 'M yran' (Esmenjaud et al., 1997; Fernandez et al., 1994; A. N icotra, personal communication).

Lesion (Pratylenchus vulnus and $P$. penetrans) and dagger (X i phenema americanum) nematodesaretwo other root parasites that create problems in the northern and mid-Atlantic U.S. peach production areas. Lesion nematodes can significantly reduce tree growth and fruit production if not controlled. $P$. vulnus is a problem in the southern $U$ nited States and California, while $P$. penetrans occurs in northern areas. Rootstocks tolerant to P. vulnus in Europe (Alcaniz et al., 1996) have been introduced. Rubira, GF 305, 'Penta', 'T etra', 'T orinel '( $P$. domestica) and P.S.B2 (P. persica from I taly) are listed as having tolerance. H owever, testing of GF 305 by M cFadden-Smith et al. (1998) showed that this rootstock was quite susceptibleto $P$. penetransand that the $C$ anadian peach seedling rootstocks $C$ hui Lum T ao and H 7338013 were more tolerant in greenhouse studies. Bailey and $G$ uardian werelesssusceptiblethan many of the European rootstocks tested. M ultiple nematode species and racesappear to be asignificant obstacle to finding a broadly adapted, nematode resistant rootstock from outside $\mathrm{N}$ orth America.

The dagger nematode can be a severe problem in the mid-Atlantic states. The major damage to peach treesfrom dagger nematode feeding is that it serves as the vector for tomato ringspot virus (TomRSV) that causes stem pitting. Since many weed species such as dandelions (Taraxacum officinale Weber) are hosts for this virus, dagger nematode resistance in rootstocks is the only way to prevent infection. Dagger nematode species are also vectorsfor nepovirusesin other regions of the world. Peach seedling rootstocks are not resistant to dagger nematodes, and therefore, new nonpeach rootstocksneed to beevaluated as to their susceptibility to the nematode or the virus. Some cherry plum P. cerasifera genotypes appear to be less sensitive to tomato ringspot virus ( $\mathrm{H}$ oy and $\mathrm{M}$ ircetich, 1984; $\mathrm{H}$ albrendt et al., 1994). Thus, rootstockssuch astheclonal rootstocks 'M r.S. 2/ 5' and 'M r.S. 2/ 8' (both P. cerasifera) from Italy (Loreti, 1994), 'VVA-1' ( $P$. cerasifera $x P$. tomentosa Thunb.) and 'VSV-1' [P. incana (Pall.) Batsch $\times P$. cer asifera] from Russia and 'A dara' (P. cerasifera) from Spain, may offer some tolerance. $\mathrm{H}$ owever, none of them have been yet tested in the U nited States for To omR SV resistance.

Soll teXtURe, PH AND fUngal PathoGENS. Peach rootstocks generally are not adapted to poorly drained, heavy clay soils or to calcareous soils where $\mathrm{pH}$ is above 7.5. Poorly drained soils result in peach tree decline or death. Weak, unproductive, chlorotic peach trees are typical when grown on peach 
roots in high $\mathrm{pH}$ soils. Alkaline soils in $\mathrm{N}$ orth A merica where new peach rootstocks can be useful include the stone fruit production areas in T exas, Colorado, and a few other locations in the western states.

A number of new hybrid rootstocks introduced from Europe were developed for calcareous soils. These include the French rootstocks 'J aspi' [ (P. dometica XP. salicina) XP. spinosa
L.], 'Julior' (P. insititia $\times$ P. domes tica), 'T orinel', 'Paramount' [ formerly 'GF 677', a natural peach-almond ( $P$. dulcis) hybrid], and 'Cadaman' ( $P$. persica $\times$ P. davidiana); the Italian rootstocks 'Barrier 1', 'M r.S. 2/ 5', 'M r.S. 2/ 8' and 'Sirio' (P. persica x P. dulcisformerly 'I.S. 5/ 22' of the Pisa series); and the Spanish rootstocks 'Adesoto 101', 'M ontizo' (P. insititia), 'Adara', 'Adarcias' (Moreno et al., 1995a, 1995b) and ' $G \times N$ 8', ' $G \times N$ 15 ' and 'G xN 22' (Felipeet al., 1997) from the GN series. Of these new rootstocksonly 'Paramount' and 'J aspi' have been tested in the U nited States. 'Paramount' does reasonably well on alkaline soils but it isvery vigorousand has not been as yield efficient as peach rootstocks (Perry et al., 2000). 'J aspi' has been very susceptible to bacterial canker when tested on an acid soil in

T able1.I mported rootstocksfor peach currently or soon to betested in theU nited Statesand their reported horticultural characteristics, nematoderesistance, and edaphicadaptability.

\begin{tabular}{|c|c|c|c|c|c|c|c|c|c|c|c|}
\hline \multirow{2}{*}{$\begin{array}{l}\text { R ootstock } \\
\text { cultivar }^{2} \\
\end{array}$} & \multirow{2}{*}{$\begin{array}{c}\text { Origin } \\
\text { (country) }{ }^{y}\end{array}$} & \multirow{2}{*}{$\begin{array}{c}\text { Species } \\
\text { code }^{x} \\
\end{array}$} & \multirow{2}{*}{$\begin{array}{c}\text { Test } \\
\text { status }^{w}\end{array}$} & \multirow{2}{*}{$\begin{array}{l}\text { Vigor } \\
\text { ratingv }\end{array}$} & \multirow{2}{*}{$\begin{array}{c}\text { Cold } \\
\text { tolerance }\end{array}$} & \multicolumn{4}{|c|}{$\begin{array}{l}\text { Nematode } \\
\text { resistance }\end{array}$} & \multirow{2}{*}{$\begin{array}{c}\text { Tolerance } \\
\text { to heavy } \\
\text { wet soils }\end{array}$} & \multirow{2}{*}{$\begin{array}{c}\text { Alkaline } \\
\text { soil } \\
\text { tolerance }\end{array}$} \\
\hline & & & & & & $\mathrm{Mi}^{\mathbf{t}}$ & $M \mathbf{j}^{\mathrm{s}}$ & Ppv & $X a^{9}$ & & \\
\hline Chui Lum Tao & China & 1 & 1 & 3 & Yes & 3 & 3 & 2 & 3 & 2 & No \\
\hline GF 305 & France & 1 & 1 & 2 & No & 3 & 3 & 2 & 3 & 2 & No \\
\hline H igama & France & 1 & 1 & 1 & No & 1 & 1 & 2 & 3 & 2 & No \\
\hline H 7338013 & Canada & 1 & 2 & 2 & Yes & 3 & 3 & 3 & 3 & 2 & No \\
\hline H 7338019 & Canada & 1 & 2 & 2 & Yes & 3 & 3 & 3 & 3 & 2 & No \\
\hline Montclar & France & 1 & 1 & 2 & No & 3 & 3 & $?$ & 3 & 2 & Some \\
\hline P.S.A5 & I taly & 1 & 3 & 3 & No & $?$ & $?$ & $?$ & 3 & 3 & No \\
\hline P.S.B2 & I taly & 1 & 3 & 3 & No & $?$ & $?$ & 2 & 3 & 2 & No \\
\hline Rubira & France & 1 & 1 & 3 & No & 3 & 3 & 2 & 3 & 2 & No \\
\hline Tzim Pee Tao & China & 1 & 1 & 3 & Yes & 3 & 3 & 2 & 3 & 2 & No \\
\hline Adarcias & Spain & 2 & 3 & 3 & No & $?$ & $?$ & $?$ & $?$ & 3 & Yes \\
\hline G x N 8 & Spain & 2 & 3 & 1 & No & 1 & 1 & $?$ & $?$ & 3 & Yes \\
\hline $\mathrm{G} \times \mathrm{N} 15$ & Spain & 2 & 3 & 1 & No & 1 & 1 & $?$ & $?$ & 3 & Yes \\
\hline$G \times N 22$ & Spain & 2 & 3 & 1 & No & 1 & 1 & 2 & $?$ & 3 & Yes \\
\hline Paramount & France & 2 & 1 & 1 & No & 3 & 3 & 3 & $?$ & 3 & Yes \\
\hline Sirio & I taly & 2 & 3 & 4 & No & $?$ & 3 & $?$ & $?$ & 3 & Yes \\
\hline Penta & I taly & 3 & 3 & 1 & No & 2 & 2 & 2 & $?$ & 1 & Yes \\
\hline Tetra & I taly & 3 & 3 & 3 & No & 1 & 2 & 2 & $?$ & 1 & Yes \\
\hline Torinel & France & 3 & 3 & 3 & No & 1 & 1 & 2 & $?$ & 1 & Yes \\
\hline Adara & Spain & 4 & 3 & 3 & No & $?$ & 1 & $?$ & $?$ & 1 & Yes \\
\hline M r.S. $2 / 5$ & I taly & 4 & 3 & 3 & No & $?$ & $?$ & $?$ & $?$ & 1 & Yes \\
\hline M r.S. $2 / 8$ & I taly & 4 & 3 & 3 & No & $?$ & $?$ & $?$ & $?$ & 1 & Yes \\
\hline Kuban86 & Russia & 5 & 3 & 2 & Yes & ? & $?$ & $?$ & $?$ & 1 & U nknown \\
\hline VVA-1 & Russia & 6 & 3 & 4 & Yes & $?$ & ? & $?$ & $?$ & 1 & U nknown \\
\hline VSV-1 & Russia & 7 & 3 & 3 & Yes & $?$ & $?$ & $?$ & $?$ & 1 & U nknown \\
\hline A desoto 101 & Spain & 8 & 3 & 3 & No & 1 & 1 & 3 & $?$ & 1 & Yes \\
\hline M ontizo & Spain & 8 & 3 & 3 & No & 1 & 1 & 3 & $?$ & 1 & Yes \\
\hline Julior & France & 9 & 3 & 2 & No & 1 & 1 & 3 & $?$ & 1 & No \\
\hline Pumiselect & Germany & 10 & 2 & 3 & Yes & $?$ & $?$ & $?$ & $?$ & 3 & No \\
\hline Barrier 1 & I taly & 11 & 3 & 1 & No & 1 & 2 & 2 & $?$ & 1 & Yes \\
\hline Cadaman & France & 11 & 3 & 2 & No & 1 & 1 & 3 & $?$ & 2 & Yes \\
\hline I shtara & France & 12 & 1 & 4 & No & 1 & 1 & 3 & $?$ & 2 & No \\
\hline M yran & France & 12 & 1 & 1 & No & 1 & 1 & $?$ & $?$ & 1 & No \\
\hline J aspi & France & 13 & 2 & 3 & No & $?$ & $?$ & $?$ & $?$ & 1 & Yes \\
\hline
\end{tabular}

zAdditional testing of compatibility with U .S. peach cultivars may be needed for Adara, I shtara, Jaspi, Pumiselect, T orinel, VVA-1, and VSV-1. Excessive suckering may occur with Adesoto 101 .

yCountry of origin and/ or initial testing.

XSpeciestype: $1=P$ runuspersica, $2=P$. dulcis $x P$. persica, $3=P$. domestica, $4=P$. cerasifera, $5=P$. cerasifera $\times P$. persica, $6=P$. cerasifera $\times P$. tomentosa, $7=P$. incana $\times P$. cerasifera, $8=P$. insititia, $9=P$. insititia $\times P$. domestica, $10=P$. pumila, $11=P$. persica $\times P$. davidiana, $12=(P$. cerasifera $\times P$. salicina) $\times P$. persica, $13=(P$. domestica $\times P$. salicina) $\times P$. spinosa. ${ }^{w} 1$ = has had limited field testing, $2=$ currently in field tests, $3=$ will be in field tests soon.

' 1 = vigor similar to 'GF 677' or N emaguard, $2=$ vigor similar to L ovell, $3=$ vigor slightly less than Lovell, and $4=$ vigor at least 30 percent less than L ovell.

uR ootstock is considered to have better tolerance to cold winter temperatures than L ovell.

tResistance to root-knot nematode (M eloidogyne incognita). $1=$ immune or resistant, $2=$ moderately resistant or some tolerance, $3=$ susceptible and ? = unknown.

sResistance to root-knot nematode (M eloidogyne javanica). $1=$ immune or resistant, $2=$ moderately resistant or some tolerance, $3=$ susceptible and ? = unknown.

rResistance to lesion nematode (Pratylenchus penetrans or $\mathrm{P}$. vulnus). $1=$ immune or resistant, $2=$ moderately resistant or some tolerance, $3=$ susceptible and ?= unknown.

qResistance to dagger nematode (X i phenema americanum). $1=$ immune or resistant, $2=$ moderately resistant or some tolerance, $3=$ likely susceptible and ? = unknown. $\mathrm{N} o$ resistance has yet been observed in peach.

PT olerance of heavy textured soils when waterlogged. 1 = good, 2 = fair, and $3=$ poor. 
the southeastern U nited States (personal observation).

On heavy or poorly drained soils, peach rootstocks are often at risk of becoming infected with fungi (Phytophthora de Bary) that cause crown rot. Similarly, all peach rootstocks are susceptible to the oak root rot fungus (Armillaria mellea (Vahl: Fr.) P. Kumm. and A . tabescens(Scop.) E mel) where it is present, regardless of soil texture or drainage. Both organisms are difficult to control or eradicate; therefore, genetic resistance to them is highly desirable in rootstocks.

$M$ any European rootstocks recently introduced to the U nited States are listed as tolerant of waterlogging. Rootstocks labeled as tolerant to waterlogged soilsinclude'J aspi', 'J ulior', 'T orinel', 'Penta', 'Tetra', 'M r.S. 2/ 5', 'Barrier 1', 'Adesoto 101', 'A dara', 'M ontizo', and the Russian rootstocks 'VVA-1' and 'VSV-1'. The season of waterlogging usually is not specified in releasenotices, and thusit isnot known whether these rootstocks are tolerant of dormant or growing season wet soil conditions. $M$ any of these rootstocks were developed in M editeranean climates that receive their rainfall in the winter. In N orth America, waterlogging can occur during the growing season. Thus, testing of these rootstocksin different climatic regions is important before release to commercial fruit growers.

M ost of the new hybrid plum European rootstocksarelisted by thebreeders as tolerant of replant sites and soil diseases. H owever, specific soil diseases usually are not identified. 'I shtara' and 'M yran' were reported by Renaud et al. (1988) to be resistant or tolerant to oak root rot ( $A$. mellea) in France. O bservations in the southeastern $U$ nited States by T.G. Beckman (unpublished data) show that these rootstocks are susceptible to A. tabescens and may not be resistant to the endemic fungal soil pathogens. These preliminary observations further warrant widespread field testing of the European disease tolerant rootstocks. These rootstocks remain untested under North American climatic conditions, but many will be included in the 2001 NC-140 regional peach rootstock test where a few of the 24 test locations will be orchard sites having a past history of peach tree short life or A rmillaria (Fr.:Fr.) Staude.

Winter temperatures. Winter cold hardiness of peach root systems varies considerably among rootstock cultivars. The absence of snow cover or some orchard floor management practicescan increasethe susceptibility of peach rootstocks to cold injury. Rootstocks that are inherently cold hardy or deacclimate at a slower rate after warm temperatures are necessary to grow peaches in cold regions. The majority of cold tolerant peach rootstocks have come from the Canadian breeding program (L ayne, 1987). Releases of the cold hardy peach seedling rootstocks Siberian C, H arrow Blood, Tzim Pee Tao, and Chui Lum Tao either have not conveyed outstanding cold hardiness to peach scion cultivars or have had some other deficiency such as susceptibility to ring, rootknot and lesion nematodes or A rmillaria and Phytophthora root rots. $\mathrm{N}$ ew cold hardy and perennial canker (Cytospora cincta Sacc.) resistant selectionsfrom theformer $\mathrm{H}$ arrow breeding program currently are being tested in a N C -140 peach rootstock test in 20 states and provinces and may be available in the future. Some of these $\mathrm{H}$ arrow selections like H7338013, H 7338019 (P. persica), Tzim PeeT ao and $C$ hui $L$ um $T$ ao delay scion bloom by 1 to $2 \mathrm{~d}$ in South Carolina (G. Reighard, unpublished data). Introduction of three Russian rootstocks, 'Kuban86' ( $P$. cerasifera $x P$. persica), 'VVA-1', and 'VSV-1' may offer more cold hardinessthan the $C$ anadian peach rootstocks since they were developed from Prunus species from colder regions that are marginal for peach production due to very cold winters and spring freezes.

\section{Peach scion and rootstock interactions}

Vigor CONTRol. Peach seedling rootstocks including brachtytic dwarfs rarely reduce scion vigor more than $10 \%$ to $15 \%$. Size control of peaches through rootstocks of other Prunus species has not been achieved satisfactorily due to incompatibility or poor tree vigor. Without graft compatible and size controlling rootstocks such as in apple, increases in peach orchard productivity via intensive training systems may be difficult to achieve. $\mathrm{N}$ ew dwarfing rootstocks for peach must reduce vigor, begraft compatible, and give good fruit production without reduction of fruit size and quality.

European rootstocks listed as mildly dwarfing (approximate percent of peach standard) include 'Ishtara' (70\%), 'Julior' (70\%), Rubira (90\%), 'Tetra' (90\%), 'M r.S. 2/ 5' (90\%), I talian peach seedlings P.S. A5 (80\%) and P.S. B2 (90\%), 'Adesoto 101' (80\%), 'Adarcias' (70\%) and 'Adara' (80\%). Semidwarfing rootstocks are 'Pumiselect' (60\%), a Prunuspumila L. selection developed in G ermany ( $\mathrm{J}$ acob, 1992), 'Sirio' (60\%) (L oreti and M assai, 1998), and 'VVA-1' (40\%) (D evyatov, 1996). The degree of dwarfing of these rootstocks will vary with the climate, soil type and site history. Without extensive geographic testing, it is uncertain if these rootstocks will perform adequatelyassize controlling rootstocks in many peach production areas. In addition, California breeders have developed size controlling rootstocks for peach (D ejong et al., 1994) that are now in advanced testing in California and thusfar have reportedly maintained yield efficiency and fruit size despite significant tree dwarfing.

\section{Commercial outlook}

$\mathrm{N}$ ew and better peach rootstocks are on the horizon, but the time from initial testing to commercial production of a selection often takes many years. $\mathrm{N}$ ew rootstocksfrom the F rance, I taly, Spain and other breeding programs that now are becoming available are complex species hybrids that must be propagated vegetatively. $\mathrm{M}$ icropropagation from tissue culture explants commonly is employed in these countries to mass produce these unique hybrid rootstocks. Due to strong grower interest this technology now has been incorporated by a few fruit tree nurseries in the U .S. and has expedited virus testing procedures at NRSP5, Prosser, Wash., and the U.S. D epartment of AgricultureA nimal and Plant $\mathrm{H}$ ealth Inspection Service in Glenn Dale, Md. Other factors still complicating the commercial release of these new rootstocks into the U.S. are patent laws and licensing agreements that must be negotiated between government agencies, nurseries, and grower groups. D espite these problems, some new rootstocks are being tested through regional and national trials such as the N C-140 regional project that evaluatesnew rootstocks for stone and pome fruits across the U.S. and Canada. This, in conjunction with new screening methods and extensive cooperation among researchers, is decreasing the time to 
evaluatepromising rootstock selections so that new releases for fruit growers can occur more frequently than they have in the past.

\section{Literature cited}

Alcaniz, E., J. Pinochet, C. Fernandez, D. Esmenjaud, and A. Felipe. 1996. Evaluation of Prunus rootstocks for root-lesion nematode resistance. $\mathrm{H}$ ortScience 31:1013-1016.

D ay, L.H. 1953. Rootstocks for stone fruits. Calif. Agr. Expt. Sta. Bul. 736.

D ej ong, T., R. Johnson, D. Ramming, J. Doyle, and K. Day. 1994. Evaluation of size controlling rootstocks for California peach, plum and nectarine production. $C$ alif. T reeF ruit A greement R pt., R eedley.

D evyatov, A.S. 1996. R oot system of plum trees on standard and dwarfing rootstocks. Fruit Var. J. 50:229-235.

Esmenjaud, D., J.C. M inot, R. Voisin, J. Pinochet, M.H. Simard, and G. Salesses. 1997. D ifferential response to root-knot nematodes in Prunus species and correlative genetic implications. J. N ematol. 29:370-380.

Felipe, A.J., J. Gomez-Aparisi, R. Socias i Company, and M. Carrera. 1997. The almond $x$ peach hybrid rootstocks breeding program at Zaragoza (Spain). Acta H ort. 451:259-262.

Fernandez, C., J. Pinochet, D. E smenjaud, G. Salesses, and A. Felipe. 1994. Resistance among new Prunus rootstocks and selectionsto root-knot nematodes in Spain and France. H ortScience 29:1064-1067.

G rasselly, C. 1987. N ew French stonefruit rootstocks. Fruit Var. J. 41:65-67.
H albrendt, J .M ., E.V. Podleckis, A. H adidi, R. Scorza, and R. Welliver. 1994. A rapid protocol for evaluating Prunus germplasm for tomato ringspot virus resistance. H ortScience 29:1068-1070.

H oy, J.W. and S.M . M ircetich. 1984. Prune brownline disease: Susceptibility of prune rootstocks and tomato ringspot virus detection. Phytopathology 74:272-276.

Jacob, H. 1992. Prunus pumila L., eine geeignete schwachwachsende Pfirsichuntererlage. Erwerbsobstbau 34:144-146.

Layne, R.E.C. 1987. Peach rootstocks, p. 185-216. In: R.C. Rom and R.F. Carlson (eds.). Rootstocks for fruit crops. Wiley, N ew York.

Loreti, F. 1994. Attuali conoscenze sui principali portinnesti degli al beri da frutta. Revista di Frutticoltura N o. 9. p. 9-60.

Loreti, F. 1997. Bioagronomic evaluation of the main fruit tree rootstocks in I taly. Acta H ort. 451:201-208.

Loreti, F. and R. M assai. 1998. Sirio: new peach $x$ almond hybrid rootstock for peach. Acta H ort. 465:229-236.

M cFadden-Smith, W., N.W. Miles, and J.W. Potter. 1998. Greenhouse evaluation of Prunus rootstocks for resistance or tolerance to the root-lesion nematode (Pratylenchus penetrans). Acta H ort. 465:723-730.

M oreno, M ., M . Tabuenca, and R. Cambra. 1995a. Adesto 101, a plum rootstock for peachesand other stone fruit. $\mathrm{H}$ ortScience 30:1314-1315.

M oreno, M ., M . T abuenca, and R. Cambra. 1995b. Adara, a plum rootstock for cherries and other stone fruit species. $\mathrm{H}$ ortScience 30:1316-1317.
N yczepir, A.P., E.I . Zehr, S.A. Lewis, and D.C. H arshman. 1983. Short life of peach trees induced by Criconemella xenoplax. Plant D is. 67:507-508.

N yczepir, A.P. and J.O. Becker. 1998. Fruit and citrus trees, p. 637-684. In: Plant and nematode interactions. Amer. Soc. Agron. Monogr. 36.

O kie, W.R., G.L. Reighard, T.G. Beckman, A.P. N yczepir, C.C. Reilly, E.I . Zehr, and W.C. N ewall, Jr. 1994. Field-screening Prunus for longevity in the southeastern U nited States. H ortScience 29:673-677.

Perry, R., G. Reighard, D . Ferree, and N C140. 2000. Performance of the 1984 N C140 cooperative peach rootstock planting. J. Amer. Pomol. Soc. 54:6-10.

Reighard, G.L., W.C. N ewall, T.G. Beckman, W.R. O kie, E.I. Zehr, and A.P. $\mathrm{N}$ yczepir. 1997. Field performance of Prunus rootstock cultivars and selections on replant soils in South Carolina. Acta H ort. 451:243-250.

Renaud, R., R. Bernhard, C. Grasselly, and F. Dosba. 1988. Diploid plum x peach hybrid rootstocksfor stonefruit trees. $\mathrm{H}$ ortScience 23:115-117.

Westcott, III, S. W., E.I. Zehr, W.C. N ewall, Jr., and D.W. Cain. 1994. Suitability of Prunusselections as hosts for the ring nemato de (Criconemella xenoplax). . . Amer. Soc. H ort. Sci. 119:920-924.

Zehr, E.I., R.W. M iller, and F.H. Smith. 1976. Soil fumigation and peach rootstocks for protection against peach tree short life. Phytopathology 66:689-694. 